Digitized by the Internet Archive in 2011 with funding from

LYRASIS members and Sloan Foundation 


\section{CONTENTS}

Introduction

Euonymus scale, Unaspis euonymi (Comstock) 6

Cottony taxus scale, Pulvinaria floccifera (W.) 8

Pulvinaria ericicola MeDonnell _._______________ 9

Pulvinaria sp. on dogwood _.____ 9

Azalea bark scale (Eriococcus azaleae) Comst. _._. 10

Fletcher scale, Lecanium fletcheri 12

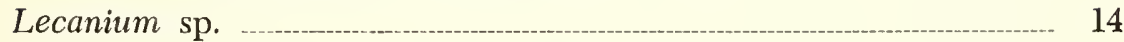

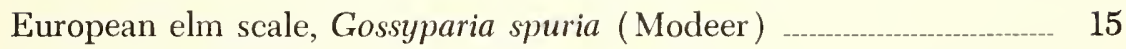

Beech bark scale, Cryptococcus fagi (Baer.) _-_ 17

Oystershell scale Lepidosaphes ulmi (L.) _ 19

Magnolia scale, Neolecanium cornuparvum (Thro.) 19

Fiorinia hemlock scale, Fiorinia externa Ferris ___ 20

Scurfy scale, Chionaspis furfura (Fitch)

Oleander scale, Aspidiotus sp.

Coconut scale, Aspidiotus destructor Sign _-_ 23

Mealybugs, Pseudococcus sp. _-____- 24

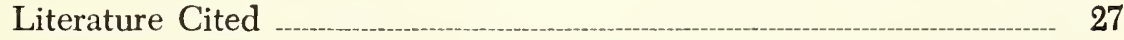




\section{FOREWORD}

The author has worked on scale insects and their control for a number of years. This bulletin is the culmination of experiments carried on during the past decade. Several of the insecticides are outstanding in their effectiveness in killing all stages of hard- and soft-shell scales whereas others were effective only against the nymphal stages. This report shows the comparative performance of chemical compounds used in his experiments. Mr. Schread's goal is the discovery of the least hazardous and most efficient method of controlling scale insects.

As of January 1, 1970, materials mentioned in this Bulletin that have been registered for use against scale insects and mealybugs on plants were as follows:

Ethion-Oil-Registered for the control of scale insects and mealybugs on evergreens, shade trees, and woody ornamentals.

Scalecide (dormant oil)-Registered for the control of scale insects on evergreens, shade trees, and deciduous trees and shrubs. Exceptions are sugar maple, beech, red-bud, Japanese maple, black walnut, butternut, hickory, and juniper.

Diazinon-Registered for the control of scale insects on arborvitae, azalea, birch, boxwood, camellia, carnation, chrysanthemum, Douglas fir, elm, gladiola, hawthorn, holly, juniper, lilac, locust, maple, oak, pine, plum, poplar, rhododendron, rose, spruce, willow, apple, etc.

Sevin-Registered for the control of scale insects on flowers, shrubs, shade trees, rose, carnation, gladiolus, chrysanthemum, lilac, arborvitae, juniper, hydrangea, azalea, maple, dogwood, birch, pine, elm, oak, etc.

Vapona-Registered for the control of mealybugs on greenhouse plants.

Malathion-Registered for the control of scale insects and mealybugs on many plants growing outdoors and under glass.

Di-Syston-Registered for the control of scales on camellia and elm; also tea scale and soft brown scale on greenhouse plants.

Systox-Registered for the control of scales on camellia, rhododendron; also mealybugs, soft brown scale, and tea scale.

Cygon-Registered for the control of scale insects on azalea, euonymus, and camellia, and mealybug on boxwood.

Baytex-Registered for juniper scale, lecanium scale, and oystershell scale.

Guthion-Registered for juniper scale, black pine leaf scale, brown soft scale, Cerococcus scale, euonymus scale, European elm scale, olive scale, and putnam scale.

The unregistered materials-Pyrenone, $7 \mathrm{~N}$ Oil, Ethion, Ethion-Thiodan, Gardona, Dylox, and Dibrom were used as experimental compounds. They may or may not be registered subsequently for use in control of scales or mealybugs or both. 


\title{
CONTROL OF SCALE INSECTS AND MEALYBUGS ON ORNAMENTALS
}

\author{
John C. Schread
}

\section{INTRODUCTION}

Many species of sucking insects attack shade and ornamental trees, shrubs, flowers, and greenhouse plants. Serious injury from them may go unnoticed until the pests are numerous and advanced symptoms of injury are obvious. Then it may be too late to prevent partial or complete loss of infested plants.

Uninformed homeowners occasionally abandon or destroy infested trees and shrubs because the plants are unsightly. Research has disclosed ways to control many scale insects on ornamentals, however, and valued plantings can be protected.

Scale insects are usually small and not easily seen in their early stages of development. Some of the species grow and multiply rather rapidly, thus becoming more obvious when mature. At that time, however, they are most difficult to control.

There are two main classes of scale insects: armored (hard-shell scales) and unarmored (soft-shell scales). The armored species live freely under the hard outer shell which is produced as the insects grow and molt. The molted skins are incorporated in waxy filaments which ultimately form the hard exterior armor or shell. The female may pass the winter as an adult under the shell, or in some instances, the insects pass the winter in the egg stage. Some species give birth to living young.

Unarmored scales are characterized by the intimate fusing of the female scale with an outer soft shell of which she is an integral part. The various species may overwinter as first or second instar nymphs, or as mature females. Occasionally a species lays its eggs in late summer or early fall and survives the winter in this stage. This class of scales secretes large quantities of honeydew in which sooty fungus grows, resulting in accumulation of an objectionable black covering on foliage, twigs, and branches. In extreme instances, this may cause as serious injury to a tree, shrub, or plant as does the feeding of the insect. There are more species of unarmored than armored scales.

An area of a leaf, twig, or branch may be scraped with a knife or finger nail to determine if scale insects are present. If a scale insect is present, it will be removed with little difficulty leaving only a small lighter or darker film-like area in contrast to the surrounding tissues. 
to 4 per cent dormant oil spray produced satisfactory results when the treatment was applied to euonymus in the spring before growth began. Treatments applied during the early growing season caused the leaves to drop, resulting in bare branches until new growth developed.

In midsummer, during the third week of July, applications of Sevin ${ }^{\circledR}$ and ethion were applied to 2-foot euonymus Emerald-Charm plants heavily infested with scale. Sevin ( $80 \%$ wettable powder) was used at the rate of 1 and 2 pounds per gallon of water and ethion (45\% emulsion) was used at 1 and 2 pints in 100 gallons of water. Four ounces of Triton ${ }^{\circledR}$ B1956 wetting agent were added to the ethion solution.

Treatments were evaluated on August 1. An 87 to 94 per cent reduction in the number of scales was noted in the plots treated with Sevin. Ethion reduced the number of scales by 82 to 86 per cent.

Control of euonymus scale on pachysandra was pursued on October 19 with Ethion-Oil ${ }^{\circledR}$ used at the rate of 1 pint in 30 gallons of water. An area of $360 \mathrm{sq}$. ft. containing a dense groundcover of scale-infested pachysandra was drenched with the treatment. Because of the denseness of plant growth and depth of leaf mulch, the probability of complete spray coverage with one treatment was low.

Six weeks after application, live and dead adults and nymphs were counted. The percentage of control is shown in Table 1. Nymphs were much more susceptible to the oil than the adults.

Control by soil treatments. The systemic known as Di-Syston ${ }^{\circledR}(10 \%$ granules) was tested on August 18, 1967, for its effectiveness in controlling euonymus scale on a dense cover of pachysandra. Di-Syston was applied on August 18 at the rate of $2 \mathrm{oz}$. of formulation per $100 \mathrm{sq}$. $\mathrm{ft}$. of soil. The treatment was drenched with water several times for about 10 days.

An assay of the results of the treatment was made on November 14, 1967. Seventy-five per cent of the free-living immature scales were killed. Innumerable newly hatched scales still under parent scales were also dead. An examination of the pachysandra plants on July 16, 1968 revealed that the plants were completely free of scales.

Table 1. Effect of Ethion-Oil on the control of euonymus scale on pachysandra

\begin{tabular}{lcccc}
\hline & & \multicolumn{2}{c}{ Scales } & Per cent \\
\cline { 3 - 5 } Insect Stage & Area of plants & Dead & Alive & control \\
\hline Adults & Stems & 150 & 306 & 32.8 \\
Adults & Leaves & 12 & 12 & 50 \\
Nymphs & Leaves & 153 & 10 & 93.8 \\
\hline
\end{tabular}

${ }^{1}$ Data based on numbers of adults and nymphs found on 5 stems and 16 leaves. 
Control. Control of the overwintered nymphs of the Pulvinaria scale on Taxus cuspidata was undertaken on two 10-foot-long taxus hedges averaging about 4 feet in height. Systox ${ }^{\circledR}$ emulsion was sprayed onto the hedges on April 30 at the rate of $1 / 2$ and 1 pint in 100 gallons of water. Triton B1956 wetting agent was used at the rate of $8 \mathrm{oz}$. in 100 gallons of complete spray.

An assay of the results of the treatments was made on May 23 by counting dead and live scales on three 5-inch twigs taken at random from each sprayed area of the hedges. Results were not promising. Seventyfour per cent of the scales were dead in the plot receiving 1 pint of Systox, and 48 per cent succumbed at the lower dosage rate.

\section{Pulvinaria ericicola McDonnell}

Biology. Pulvinaria ericicola overwinters as a nymph and has one generation per year. A small percentage of nymphs on Azalea kaempferi and A. hinodegiri had reached maturity and laid eggs by June 9. During the following 10 to 14 days, most of the adult scales produced eggs which started to hatch on June 23 (in the New Haven area). At this time the first instar nymphs were observed dispersing throughout the plants. In one instance, there were 1,207 scales on 24 inches of twigs.

Control. Foliar sprays were directed against nymphs and adults infesting Azalea kaempferi. In one test, Ethion 47\% emulsion was applied to Azalea kaempferi during mid and late summer at the rate of 1 and 2 pints of formulation in 100 gallons of water. Triton B1956 wetting agent was added to the sprays at the rate of 4 ounces per 100 gallons. Treatments were evaluated 2 weeks later. All 5,244 scales on 240 lineal inches of azalea twigs were killed. No plant injury occurred.

A combination insecticide containing malathion $20 \%$ and chlordane $21 \%$ was brushed onto the infested azalea branches on July 12 at the rate of 1 and 2 pints of formulation in 100 gallons of water ( 1 or 2 teaspoons/1 gal.). Triton B1956 wetting agent was added to each solution of insecticide at the rate of 4 ounces per 100 gallons. A post-treatment count of 16,433 scales showed that all had been killed by the treatment. None died on untreated plants. No plant injury was noted.

In an additional test Ethion-Oil was sprayed onto scale-infested plants on August 22, at the rate of 4 pints in 100 gallons of water ( 4 teaspoons/ 1 gal.). A hand-pressure sprayer was used to apply the treatment. There were seven plants, averaging 34 inches in height, in the test. An assay of results on September 14 showed a total of 396 dead scales and no live ones on 21 lineal inches of twigs taken at random from the sprayed plants. No phytotoxicity was indicated.

\section{Pulvinaria sp. on Dogwood}

Foliar sprays were directed against an unknown species of pulvinaria infesting dogwood. In mid-July foliar applications of Ethion $47 \%$ and 

Overwintering scales mature in the spring. Both the females and males are enclosed in small wooly or felt-like sacks. The males have two white wings (Weigel and Baumhofer 1948). Eggs deposited at this time begin to hatch during the fourth week in June or earlier (June 23, 1968, June 20, 1954, June 18, 1957, June 27, 1959). Hatching may continue until after mid-July. The pinkish young crawl upward over the twigs and occasionally onto the leaves. There may be as many as one to five individuals per inch of twig. The young migrants settle down in the axils of leaves or stems, in bark crevices and along the main branches as far as the ground. For unknown reasons, about one-third of the population dies before winter. There is only one generation of the scale insect each year in Connecticut.

Control by spray treatments. Foliar applications were undertaken on August 30, 1968, to determine the effectiveness of emulsifiable concentrates of the following insecticides: 25\% Gardona ${ }^{\circledR}, 40.5 \%$ Dylox ${ }^{\circledR}$, and Pyrenone ${ }^{\circledR}$ at the rate of 1 and 2 pints of formulation in 100 gallons of water. Four ounces of Aqua-Gro ${ }^{\circledR}$ wetting agent were added to each complete spray mixture. There were three 28 -inch azaleas (large white flower) in the test. A 3-gallon hand-pressure sprayer was used to apply the treatments.

Results of the treatments are shown in Table 2. Gardona was wholly effective at the low concentrations. Dylox gave good results at both concentrations, though the higher one ( 2 pints) produced slightly better results. Pyrenone was not effective.

Control by soil treatments. Di-Syston $5 \%$ granules were evaluated for their effectiveness against azalea bark scale on July 21 at the rate of 6 and $12 \mathrm{oz}$. of formulation per 3 foot andromeda plant. The soil was removed from under each plant to a depth of 2 inches from the base

Table 2. Control of azalea bark scale

\begin{tabular}{lccccc}
\hline & $\begin{array}{c}\text { Dilution, pints } \\
\text { Insecticide }\end{array}$ & \multicolumn{2}{c}{ Scales $^{1}$} & Per cent \\
\cline { 3 - 4 } Ger & 100 gal. & Dead & Alive & control \\
\hline Gardona & 1 & 78 & 0 & 100 \\
Dylox & 2 & 61 & 0 & 100 \\
Dylox & 1 & 71 & 5 & 93.4 \\
Pyrenone & 2 & 44 & 0 & 100 \\
Pyrenone & 1 & 71 & 23 & 75.5 \\
Checks & 2 & 54 & 23 & 70.1 \\
\hline
\end{tabular}

${ }^{1}$ Twelve lineal inches of azalea twigs were examined for the presence of scales per treatment. 
Fig. 6. Adult female fletcheri scales and eggs on taxus.

to the outer circumference of the branches. The granules were sifted evenly into the soil in the saucer-like depression and covered with the dirt that had been removed. The treatment was drenched with water four times during the following week.

The evaluation was made by counting dead and live scales on eight 4.5 inch (aver.) twigs per rate of treatment and check. Many dead scales dropped from the sprayed plants and were not accounted for. There were 19 dead and 51 live scales on the plants which received the $6 \mathrm{oz}$. treatment and 34 dead and 13 live ones on those treated with $12 \mathrm{oz}$. A count of live scales before treatment indicated an average of 79 , with a range of 8 to 180 on an average 5 inch twig.

Soil treatment with Di-Syston was not as effective as some of the foliar sprays.

\section{Fletcher Scale, Lecanium fletcheri Cockerell}

Biology. Lecanium fletcheri scale, sometimes referred to as the arborvitae soft scale or Fletcher scale, is widely distributed, occurring on many varieties of plants growing outdoors and under glass. At first the species was of little importance, found principally on arborvitae. However, as more and more species and varieties of taxus were propagated in nurseries, the scale insect became more of a pest on them than on other plants. When branches and the underside of the foliage are heavily infested with scales, serious weakening of a plant may occur. Under these conditions needles may lose color and drop prematurely. The insects secrete honeydew which acts as a culture media for sooty fungus resulting in unsightly blackening of affected plants. 
taken on June 19, 1968, when 90 to 95 per cent of the eggs had hatched. (Initial hatch occurred between the 10th and 12th of June.) Ethion-Oil was applied with a hydraulic sprayer at the rate of 2 quarts in 100 gallons of water. Pump pressure was 400 psi. There were about 2 acres of 18- to 24-inch T. hicksi plants in the test. Data taken on June 24 showed that all newly hatched scales were dead.

\section{Lecanium sp.}

Control on locust. An unknown species of Lecanium (perhaps corni) causing serious injury to locust was found to be in the egg stage on June 17, 1963. An examination of 47 female scales showed an average of about 500 eggs per individual, none of which had hatched. Five 12foot trees were sprayed on June 17 with Ethion-Oil used at the rate of 3 quarts in 100 gallons of water.

On July 3, 15 female scales were dissected to determine if the eggs had been killed. All appeared to be hatching and many of the young scales had emerged and were dispersing over the twigs, branches, and foliage. A second examination of the adult scales on July 24 indicated all eggs had hatched, and except for a few stragglers all of the young had left the parent scales. Examinations of the locust trees showed that the Ethion-Oil residue had resulted in complete mortality of the young scales as they wandered over the plants.

Control on barberry. The effect of Cygon 45.3E at the rate of 2 pints in 100 gallons of water was evaluated against a species of Lecanium (probably corni) infesting 2-foot barberry plants. Two pints, rather than $1 / 2$ or 1 pint, were used because the scales were in advanced stages of nymphal development at the time of treatment on May 6, hence would probably require a stronger concentration for control than would newly hatched individuals. An assay of results made 7 days after treatment indicated 312 dead and 1 live scale on 22 lineal inches of barberry twigs.

Control on blueberry. Effects of six insecticides on highbush blueberry for the control of Lecanium corni are given in Table 3. With the exception of Sevin (May 6) all of the materials were used on April 11 to kill overwintered first instar scales before plant growth and insect activity commenced in the spring.

Control of Lecanium scale on highbush blueberry was complete with Sevin, Baytex ${ }^{\circledR}$, and Guthion ${ }^{\circledR}$. Cygon data at the 1 pint dilution were not available. It is expected, however, that it would be comparable in effectiveness to Sevin, Baytex, and Guthion. Di-Syston was effective only at the 1 pint dilution, whereas Dibrom was mostly ineffective at both dilutions.

In another series of experiments, control of overwintered nymphs of Lecanium corni on highbush blueberry was undertaken with oil sprays 
Table 3. Control of Lecanium corni on highbush blueberry

\begin{tabular}{|c|c|c|c|c|}
\hline \multirow[b]{2}{*}{ Material } & \multirow{2}{*}{$\begin{array}{l}\text { Dilution, pints } \\
\text { per } 100 \text { gal. }\end{array}$} & \multicolumn{2}{|c|}{ Scales } & \multirow{2}{*}{$\begin{array}{l}\text { Per cent } \\
\text { control }{ }^{1}\end{array}$} \\
\hline & & Dead & Alive & \\
\hline $46 \%$ Cygon & $\begin{array}{l}2 \\
1 / 2\end{array}$ & $\begin{array}{r}312 \\
48\end{array}$ & $\begin{array}{r}0 \\
16\end{array}$ & $\begin{array}{r}100 \\
75\end{array}$ \\
\hline $47 \%$ Baytex & $\begin{array}{l}1 \\
1 / 2\end{array}$ & $\begin{array}{l}20 \\
46\end{array}$ & $\begin{array}{l}0 \\
0\end{array}$ & $\begin{array}{l}100 \\
100\end{array}$ \\
\hline $26 \%$ Di-Syston & $\begin{array}{l}1 \\
\frac{1}{2}\end{array}$ & $\begin{array}{l}37 \\
33\end{array}$ & $\begin{array}{r}0 \\
40\end{array}$ & $\begin{array}{l}86 \\
45\end{array}$ \\
\hline $64 \%$ Dibrom & $\begin{array}{l}1 \\
1 / 2\end{array}$ & $\begin{array}{l}18 \\
57\end{array}$ & $\begin{array}{r}11 \\
186\end{array}$ & $\begin{array}{l}62 \\
23\end{array}$ \\
\hline $18 \%$ Guthion & $\begin{array}{l}1 \\
1 / 2\end{array}$ & $\begin{array}{l}33 \\
62\end{array}$ & $\begin{array}{l}0 \\
0\end{array}$ & $\begin{array}{l}100 \\
100\end{array}$ \\
\hline $25 \%$ Sevin & $\begin{array}{l}1 \\
y / 2\end{array}$ & $\begin{array}{l}278 \\
236\end{array}$ & $\begin{array}{l}0 \\
0\end{array}$ & $\begin{array}{l}100 \\
100\end{array}$ \\
\hline Untreated checks & & 0 & 162 & \\
\hline
\end{tabular}

${ }^{1}$ Data were taken from an average of 11 twigs (6" ave. length) per rate of treatment and checks.

on April 6. Scalecide ${ }^{\circledR}+96 \%$ and $7 \mathrm{~N} \mathrm{Oil}+98 \%$ were used at the rate of $1 \frac{1}{2}$ and 3 gallons in 100 gallons of water. In addition, Ethion $45 \%$ emulsion was used at the rate of $1 / 2$ and 1 pint in 100 gallons of water. Triton B1956 wetting agent was added to the Ethion solution at 8 ounces per 100 gallons. Each treatment was repeated once on 5- to 6-foot plants. The oil sprays killed all of the scales, whereas Ethion indicated 8 per cent kill at the lowest and 72 per cent at the highest concentrations.

\section{European Elm Scale, Gossyparia spuria (Modeer)}

Biology. The European elm scale is fairly common on elms in Connecticut. It occurs most often on young trees although occasionally it may be destructive to much larger ones, especially 18- to 30 -inch caliper street trees.

The unarmed scales are most noticeable as they approach maturity. They are reddish or dark purplish brown and are enclosed at the perimeter and towards the underside with a whitish waxy secretion resembling cotton. Males mature in April or May (McDowell 1960). Mature females average $2.5 \mathrm{~mm}$ in length and eggs are laid early in June inside the females. The nymphs are born alive after the middle of June. In 1965, only 5 per cent of the eggs (inside the females) had hatched by July 9 . On July 20,60 to 70 per cent of the young were present, however, no growth was indicated. Most of the nymphs had crawled to the underside of the leaves where they settled close to the mid-rib. Counts indicated an average of 25 scales in a range of 5 to 45 
per leaf. By late summer all young scales crawl from the leaves to twigs, branches, limbs, and trunk where they overwinter in bark crevices. Growth is resumed in the following year.

Control by spray treatments. An experiment to control the scales was undertaken on August 3 when 98 per cent of the first instar nymphs were present. Sevin flowable was used at the rate of 1 and 2 pints per 100 gallons of water. Triton B1956 wetting agent was added at the rate of 4 ounces in 100 gallons. There were 21, 20- to 25-foot trees per rate of treatment and untreâted checks. A 300-gallon hydraulic sprayer and a 4 nozzle hand boom was used to apply the treatment. Data taken on August 18 indicated complete control of the scales with both dilutions of Sevin. There was an average of 176 live scales on 10-inch twigs taken from unsprayed trees.

In an additional test undertaken on August 29, 1966, Diazinon ${ }^{\circledR}$ $48 \%$ emulsion was used at the rate of 1 and 2 pints in 100 gallons of water and Ethion-Thiodan ${ }^{\circledR} 25 \%$ emulsion at the rate of 1,2 , and 4 pints in 100 gallons of water. These were applied as foliar treatments to an average of 18 trees per rate of treatment. Triton B1956 was added to each prepared spray. Evaluation of the treatment was made October 17 by examining dead and live scales on an average of 72 lineal inches of twigs and small branches per rate of treatment and untreated checks (Table 4). Diazinon was more effective at 1- and 2-pint rates than Ethion-Thiodan at the 4-pint rate.

Control by soil treatments. Cygon $10 \%$ and Di-Syston $10 \%$ granules were used as soil treatments on March 31, 1967. They were evenly applied to the surface of the soil (from the base of the trees to the perimeter of the branches) at the rate of 2,4 and $8 \mathrm{oz}$. of formulation per inch of tree caliper. Two 15-foot trees were used in each treatment and check. No raking or watering was done.

Results of the treatments assayed August 21 appear in Table 5. Effective control of European elm scale with Cygon was obtained at the rate of 8 ounces of formulation to each one inch of tree caliper. Di-Syston was effective at a 4 ounce rate per inch of tree caliper. Two ounces of Cygon gave much better control than 2 ounces of Di-Syston.

Table 4. Control of European elm bark scale with sprays

\begin{tabular}{lccccc}
\hline & Dilution, pints & \multicolumn{2}{c}{ Scales } & Per cent \\
\cline { 3 - 3 } Insecticide & per 100 gal. & Dead & Alive & control \\
\hline Diazinon & 1 & 469 & 85 & 84.6 \\
Diazinon & 2 & 502 & 23 & 95.6 \\
Ethion-Thiodan & 2 & 25 & 84 & 22.9 \\
Ethion-Thiodan & 4 & 272 & 90 & 75.1 \\
Untreated checks & & & 548 & \\
\hline
\end{tabular}


existing on introduced and native beeches growing near Halifax, Nova Scotia, for over 20 years. He postulated that "a more complete study of its geographical distribution might conceivably indicate that it was indigenous."

Since the early nineteen hundreds the scale has spread throughout the Maritime Provinces of Canada and New England, also parts of New York, Pennsylvania, and the middle Atlantic States. It was first believed, both in Europe and in North America, that the scale insect was responsible for the decline and ultimate death of native and introduced beech trees. However, research has indicated that the fungus Nectaria coccinea var. faginata Lohman, Watson and Ayres infected the trees infested by the insect (Shigo 1963). The fungus enters beech trees through minute feeding punctures induced in the bark by the scale insects and through bark killed by the insect.

Seriously infested trees may die in a few months. Early developing foliage may be sparse. Later in the spring the leaves turn yellow and then brown and usually continue to hang on the tree throughout the summer months.

A survey made in Hartford County during the middle nineteen thirties indicated 6.4 per cent of 3,759 trees were infested with beech bark scale (Holbrook 1934). The percentage of diseased trees was not mentioned.

The scale insect is a soft-bodied species. It overwinters as a lightyellow first instar nymph. Maturity is attained in the spring, when the female scale is pale yellow (Hawboldt 1944), wingless, spherical, and about $0.8 \mathrm{~mm}$ long. Whitish wool-like waxy threads cover the body. Ehrlich (1934) states, "the insect is a typical coccid, with oviparity, motile first instar nymphs, degenerate parthenogenetic adult females, and male unknown." A light infestation may occur in bark crevices. An uncontrolled infestation expands until the bark is covered with a white felt-like mass.

Pale yellow eggs are deposited from July 1 to 15 . They may hatch at the end of July, but most of the hatch is in August. Nymphs cease crawling in mid to late September (Ehrlich 1934). After hatching the nymphs wander over the bark for a while before settling down.

Surveys made in Connecticut during several recent growing seasons provided information relating to beech bark scale egg deposition and hatching in Litchfield and New Haven counties. Considerable variation occurred. In the towns of New Milford, Washington, and Hamden, many thousands of eggs were examined on native beech trees on July 10, 13, and 15,1964 . None had hatched. Hatching began about July 20 in Hamden and was completed by August 21. In 1965 and 1966 the hatch had not occurred in Hamden by July 22 and July 19 respectively. 
During these seasons $(1964,1965,1966)$, egg hatch was extremely slow in getting started in Washington and New Milford. It continued this way in 1964 until mid-September, when a minimum of egg hatch was recorded. In 1965 the egg hatch did not start in these two towns until after September 20.

Control. Control of the beech bark scale has in the past been effected with several insecticides such as lime-sulfur, nicotine sulphate, kerosene-soap and oils. More recently Ethion-Oil used as a delayeddormant treatment at the rate of 2 gallons in 100 gallons of water prevented hatching of 50 per cent of the insects' eggs. Cygon $25 \%$ emulsion diluted at the rate of one pint in 100 gallons of water killed all of the eggs when the treatment was applied in late May and early June, 1965.

\section{Oystershell Scale, Lepidosaphes ulmi (L.)}

Biology. The oystershell scale is a serious pest, attacking more than 100 varieties of deciduous trees and shrubs. It feeds on trunks, branches, and twigs. Heavily infested plants may die. Feeding causes a drying out, cracking, and curling of the bark (Schread 1954). Female scales are brownish-gray, about $1 / 8$ inch long, and appear like tiny oyster shells.

There is only one generation a year in Connecticut. Eggs were present under all adult female scales examined on pachysandra on August 31,1966 . The insect remains in the egg stage over winter. Hatching usually commenced during late May and continued into mid-June. Over 50 per cent of the eggs usually hatched during the first week of June. However in 1967, hatching did not commence until June 10.

Control. Complete control of the oystershell scale on lilac was obtained on June 4 with Ethion-Oil spray used at the rate of 3 qts. in 100 gallons of water. Most of the eggs had hatched at the time of treatment. The nymphs that had dispersed in addition to the ones still under parent scales were killed by the spray.

\section{Magnolia Scale, Neolecanium cornuparvum (Thro.)}

Biology. The magnolia scale attacks many deciduous and evergreen trees and shrubs in the magnolia family. Serious infestation may cause deformed twigs and small leaves, ultimately resulting in dieback of part or all of a plant.

The scale is one of the largest occurring in North America. Mature females are about $1 / 2$ inch long, soft, dark lustrous brown, convex and smooth with a white waxy bloom. Males are gray, very small, and flat (Britton 1933). The nymphs are blackish and waxy in appearance. They occur in greatest numbers on the underside of twigs and branches. Counts have indicated an average of 300 individuals on 9 inch random sampling of magnolia twigs. 
Fig. 10. Adult oystershell scales on lilac twig.

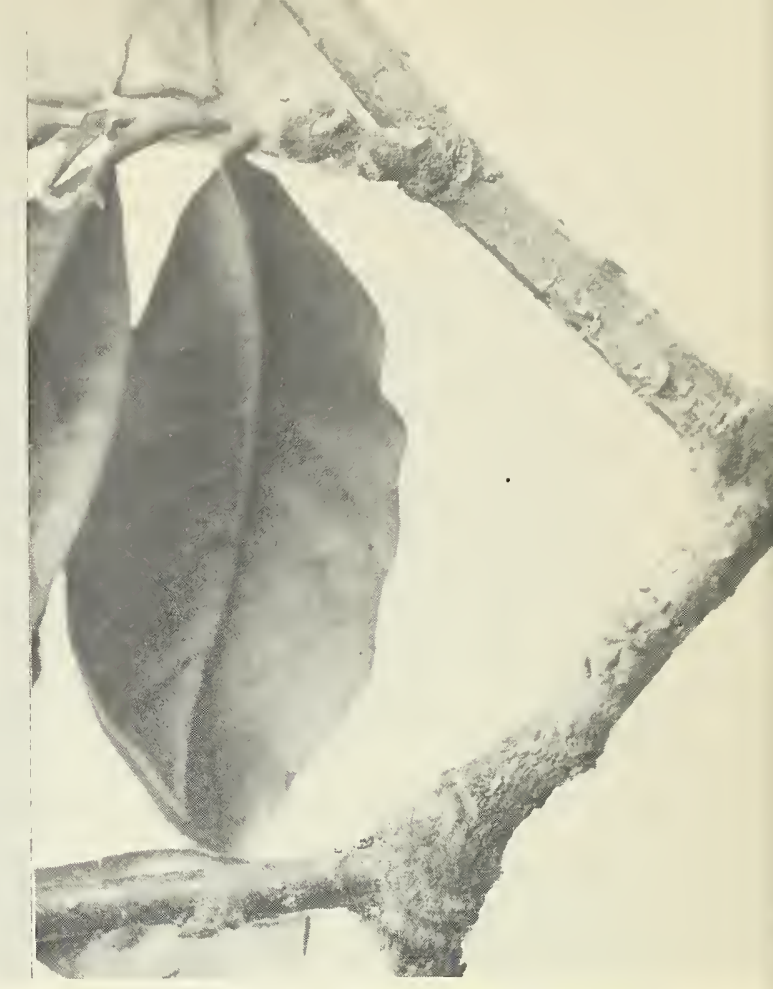

Fig. 11. Immature magnolia scales.

Scales reach maturity during late August and September at which time eggs are present inside the females. They give birth to live young in September and early October. Usually all first instar nymphs are present before the third week in October at which time hibernation commences. Growth is resumed in April of the following year. There is one generation a year.

Control. One half of a 6-foot Magnolia soulangeana was sprayed on October 19 with Sevin $80 \%$ wettable powder at the rate of 1 pound and the remaining half at $1 / 2$ pound in 100 gallons of water. Control data taken several months later indicated complete mortality of all immature scales.

\section{Fiorinia Hemlock Scale, Fiorinia externa Ferris}

Biology. The Fiorinia hemlock scale is a relatively new and serious pest of hemlock in Connecticut. It may also attack fir, spruce, and taxus. Although it occurs most often in ornamental plantings, it has caused considerable injury to native hemlock stands in this state.

Another species of scale insect, Aspidiotus ithacae, is also a pest on native hemlock. There has been some confusion as to which one causes most of the injury to ornamental and native hemlock in certain areas. A description of the Fiorinia scale will help to distinguish the species from others. 


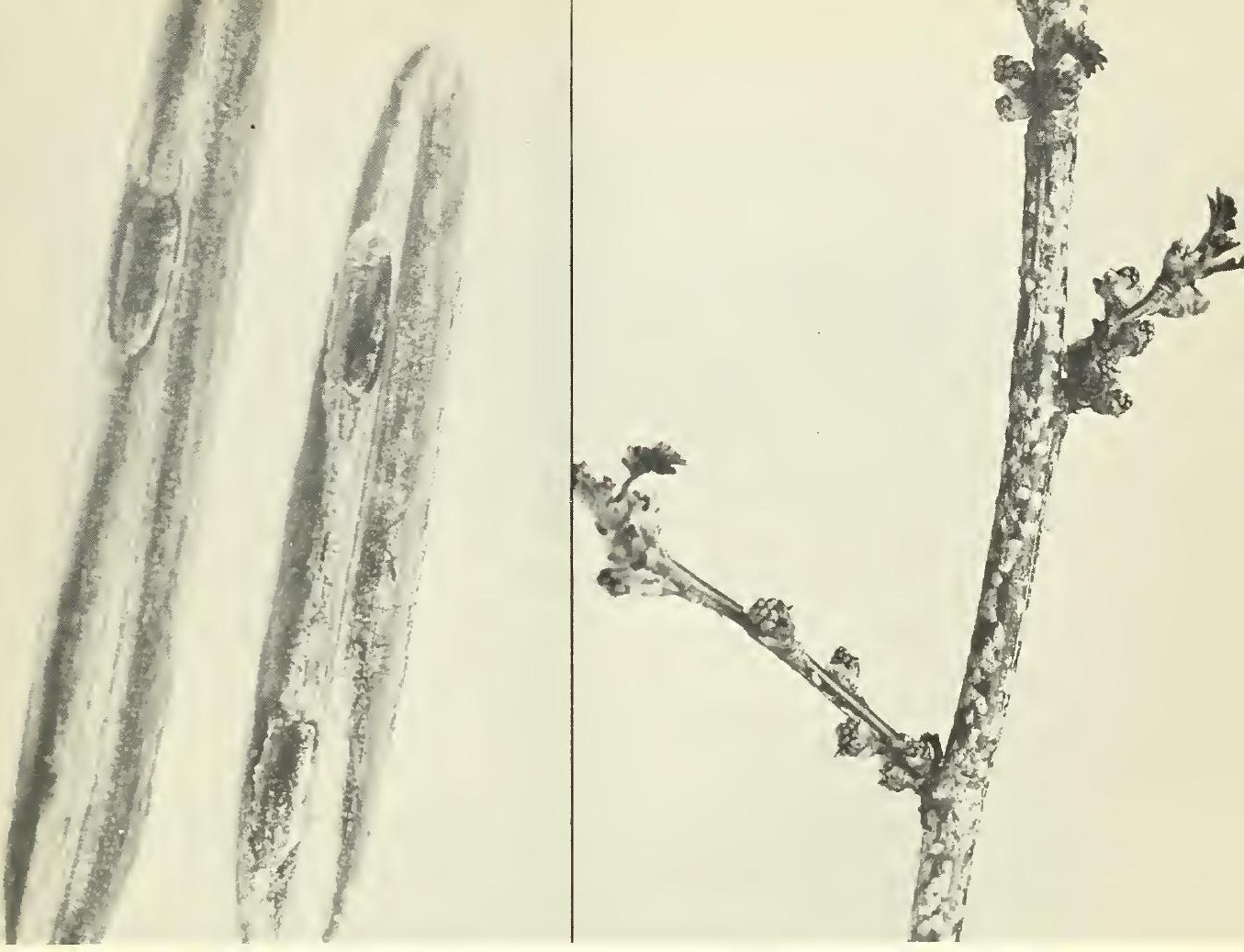

Fig. 12. Fiorinia externa scale on the underside of hemlock needles.

Fig. 13. Scurfy scales on currant.

The males and females of the Fiorinia scale are elongate. The mature female is yellowish with a slight tinge of brown. The males are white and narrower than the female (Duda 1957).

The female Aspidiotus scale is "circular in outline, somewhat raised above the bark, especially in the center where there is a small nipple, differing in color from the other portion ... armor of the full-grown male scale is nearly always elongated, with the nipple near one end" (Britton 1901). The young are lemon-yellow and extremely active, crawling from infested to new uninfested foliage during mid to late June and early July and again in mid September and later.

A seriously infested tree indicates unhealthy foliage. Needles turn yellow and drop prematurely. The vigor of the tree is greatly reduced and when infestation is permitted to continue, areas such as the crown or all of the tree may die.

The insects occur on the underside of the needles. When the mature males and females are present in great number, their waxy secretions impart a whitewashed appearance to the foliage. There are two generations of the species a year in Connecticut. In some seasons female scales may require 100 days to mature. Eggs are produced over a long period of time and continue to hatch throughout the summer (Wallner 1964). 
Control. The Fiorinia scale may be controlled with dormant oil sprays and with Cygon used in late June and early July, and again in mid September. Control of the insect on balsam fir, Abies balsamea, was undertaken on July 3 using Ethion-Oil at the rate of two pints in 100 gallons of water and applied to two 10- to 12-foot trees with a mist blower. Data taken on July 12 indicated all nymphs and adults had been killed by the treatment. There were 316 dead nymphs and 107 dead adults on 20 needles taken at random from the trees.

\section{Scurfy Scale, Chionaspis furfura (Fitch)}

Biology. The scurfy scale is a pest of dogwood, apple, hawthorn, elm, ash, and willow. The bark of heavily infested trees or shrubs have a dirty-whitish scurfy appearance. Under such conditions growth is retarded and part or all of an infested plant may die.

The insect is a native species occurring most often in the east and northeastern part of the country. Female scales are roughly pearshape in outline and grayish in color. The males are slender with narrow parallel sides and white in color. The scales occur in greatest numbers on the shaded side of limbs and branches. This species winters in the egg stage under female scales. The eggs are laid in October (Garman and Townsend 1952). There is but one generation a year.

Control. Control tests were intended to kill overwintering eggs before they hatched in April. Scalecide 96\% and $7 \mathrm{~N}$ Oil were used on April 4 at the rate of $1 \frac{1}{2}$ and 3 gallons of Scalecide and 3 gallons of $7 \mathrm{~N}$ Oil in 100 gallons of water ( 2 to $3 \mathrm{oz} / \mathrm{gal}$.). Results of the tests assayed on May 29 indicated complete kill of eggs by both materials.

\section{Oleander Scale, Aspidiotus sp.}

Biology. The oleander scale, sometimes called the ivy scale, is one of several species of scale insects that may attack orchids in greenhouses. It also infests palms and a long list of additional tropical and semitropical plants growing under glass in Connecticut. The insect is found occasionally in this latitude on plants growing outdoors during the summer months. It does not, however, survive our winter climate.

The insect multiplies rapidly and may literally coat the foliage of its host plants with immature and adult scales. Being a sucking insect, it extracts the life giving plant juices from its hosts causing a paling of the leaves, deterioration of the plant, and unless controlled, the death of part or all of the plant.

The adult scale is flattened, more or less circular and about the size of the head of a common pin. The female scale is light yellowishred in color whereas the male scale is white, smaller and more abundant than the females. 
Control on palm. Control of the oleander scale on palm was undertaken in a greenhouse on January 24. Sevin 4 flowable was sprayed onto the fronds of 10,2 - to 4 -foot plants at the rate of 1 ounce of formulation in 1 gallon of water. A 3-gallon hand-pressure sprayer was used to apply the treatment. An assay of the condition of hundreds of scales two weeks later indicated 96 per cent control. The treatment had effectively killed most first instar scales before they emerged from under the parent scales.

Control on orchids. A serious infestation of oleander scale on orchids in a 20,000 cubic foot greenhouse was brought under control by fumigating the area with 41 per cent Vapona ${ }^{\circledR}$ emulsion volatilized from a "hotplate" at the rate of 1.5 ounces per 10,000 cubic feet of greenhouse space. The first treatment was undertaken on December 20 and repeated three times at about 7-day intervals.

Control of free living immature scales was obtained with each release of Vapona. However, eggs appeared to escape the effects of the fumigation. In addition, female scales continued to lay eggs which subsequently hatched. (Counts indicated an average of 29 eggs in a range of 8 to 52 per female.) Examination of orchid leaves 8 days following the second treatment showed 230 dead and 45 live ones or 84 per cent control. An assay of scale mortality several days following the fourth treatment indicated no live nymphs and 96 per cent kill of female scales.

\section{Coconut Scale, Aspidiotus destructor Sign}

Biology. From time to time the coconut scale becomes an unsightly pest on palms growing under glass. The insect is a tropical and subtropical species which does not survive the winter in the open in Connecticut. It may, however, be brought into greenhouses on plants introduced from the South.

The adult female scale is about the size of the head of a common pin. It is flattened, waxy, whitish, or brownish in appearance. The male scale is similar to the female in appearance and in texture, and is more or less rounded in outline (Cockerell 1897). The insect infests all areas of a palm attaching themselves to the leaves, stems, and heavy basal area of the plant.

Control. A control experiment was undertaken with heavily infested 4- to 6-foot palms growing in 35, 9-inch wooden tubs ( 1 to 4 plants/tub). A pre-treatment count of scales indicated an average of 313 per 10 inch palm leaflet.

Sevin $80 \%$ wettable powder diluted at the rate of 2 pounds in 100 gallons of water was sprayed onto the palms three times at intervals of about 18 days. Examination of the plants 14 days following the first treatment showed that all of the immature scales (ave. 750/10-inch frond) were killed whereas adult mortality was 42 per cent. A final assay showed that adult mortality was complete. There were 127 dead adults on an average 24 -inch palm stem examined. 


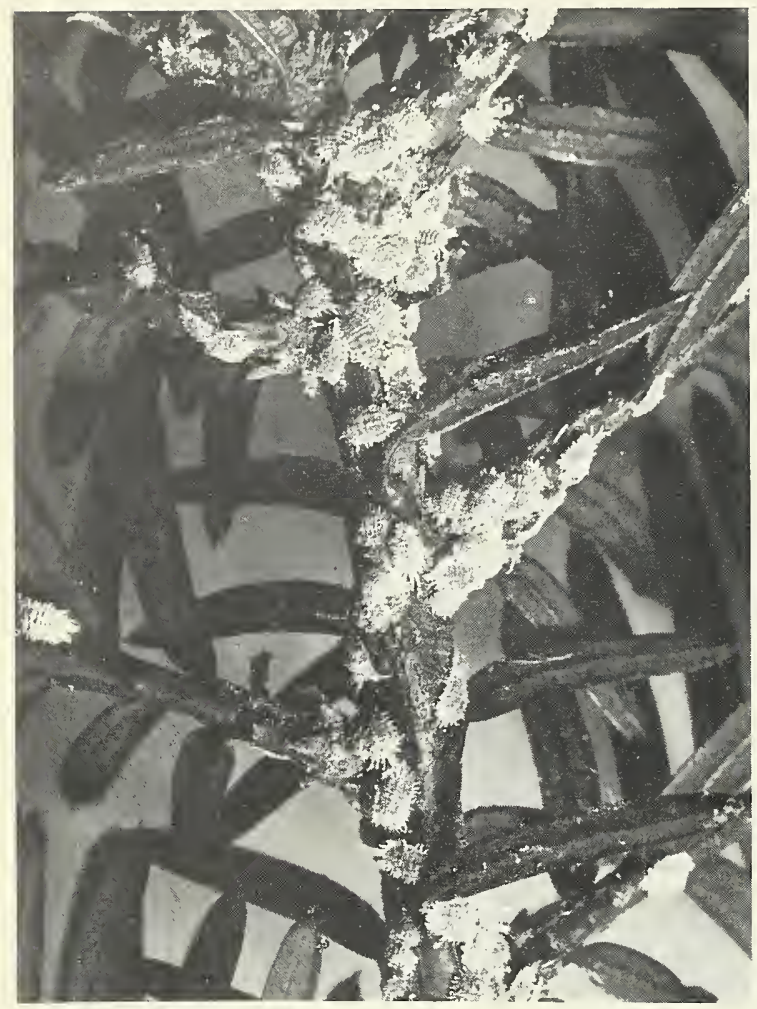

Fig. 14. Mealybugs on taxus.

\section{Mealybugs, Pseudococcus sp.}

Biology. Mealybugs feed on many varieties of trees, shrubs, and other plants. Several hundred or more are listed in current literature. A few of them are fruit trees, catalpa, chestnut, citrus, boxwood, privet, honeysuckle, grape, maple, chrysanthemums, coleus, palm, lantana, salvia, petunia, gladiolus, and grasses.

Injury to host plants is accomplished by feeding and through the secretion of a colorless fluid commonly referred to as honeydew. When the insects are numerous, quantities of the honeydew accumulate on all of the aerial parts of a plant. Sooty mold grows in the secretion causing an unsightly dirty brown to black appearance. Plants are sometimes as seriously injured by the honeydew and sooty mold as by the insect. Loss of color, wilting, and frequently death of part or all of the plant (particularly annuals and herbaceous plants) may follow.

In recent years taxus has been affected by two species of mealybugs: Pseudococcus cuspidatae, and a Pseudococcus species which is closely 
related to comstocki. The first species, $P$. cuspidatae, occurs singly or in small groups on the main stems and on the underside of the branches of taxus plants. They hibernate as very small nymphs under bark scales, and in crevices. They resume activity in April of the following year. Feeding is done by inserting their long, slender mouth parts into the bark and sucking the sap. As they grow, a waxy excretion accumulates over the surface of the body becoming more dense as the insect grows. They reach maturity in late June and early July. The species gives birth to live young, most of which appear by the end of July. The males surround themselves with a white case in which they change to twowinged adults. They die very soon after mating (Metcalf and Flint 1951). The nymphs are flat and yellow without noticeable waxy excretion. There is one generation a year (Schread 1961).

A second species, Pseudococcus sp., is a general feeder on a number of species of taxus. It has been more abundant on Taxus capitata. The young of the first generation appear in late June or early July with complete hatch by the 20th, and those of the second generation in September. Hibernation takes place in the immature stage under bark scales, in crotches, and crevices (Schread 1954).

A third species commonly known as the long-tailed mealybug, Pseudococcus adonidum, occurs on plants growing under glass and out-ofdoors. There are several generations a year on plants growing in the open and continuous overlapping of a number of annual generations on plants growing in greenhouses where high temperature and humidity may allow a complete generation in about 6 weeks.

Control by spray treatments. An experiment in control of Pseudococcus cuspidata was started on May 29 using Sevin 4 flowable at the rate of 1 and 2 pints in 100 gallons of water. In addition Ethion-Oil was also used at the rate of $1 \frac{1 / 2}{2}$ and 3 quarts in 100 gallons of water. Mealybug infested plants used in the tests were 3 to 4 foot Taxus hicksi and 2 to 3 foot T. cuspidata. Three plants of each species were sprayed with the two dilutions of each pesticide. The experiment was replicated twice.

Examination of the plants in mid-June showed that both Sevin and Ethion-Oil gave complete control without injury to the plants.

In an additional experiment undertaken on May 22, Ethion-Oil was applied to 60, 12-inch Taxus densaforma infested with Pseudococcus sp. at a rate of $2 \frac{1}{2}$ quarts in 100 gallons of water. A 300-gallon hydraulic sprayer was used for the purpose. Tank pressure was maintained at 400 lbs. An examination of the plants on June 26 indicated complete control of adults and the crawling stages of the insect.

A third experiment designed to control Pseudococcus comstocki on strawberry begonia was started on May 26 using Ethion-Thiodan formulation at the rate of $1^{1 / 4}$ pints in 100 gallons of water. There were 24 
plants growing in 4-inch clay pots in the test. Each plant (including the pot) was dipped three consecutive times into the pesticide solution. A pre-treatment count on mealybugs indicated an average of 3.4 per leaf in a range of 1 to 7 . Data taken in mid-June showed that mealybug mortality was complete with Ethion-Thiodan. The material did not injure the plants.

Control by soil treatments. Several systemic insecticides have been used as soil treatments to control mealybugs. Their usefulness has been clearly demonstrated under controlled conditions on plants growing under glass. It is now known that disulfoton (Di-Syston) can be used to control the greenhouse mealybug, Pseudococcus, on coleus (Labiatae blumei).

In experiments undertaken in a greenhouse on August 25, Di-Syston $10 \%$ granules were distributed evenly at the rate of $1 / 2$ and 1 teaspoon for formulation onto the surface of the soil of 4-inch clay pots in which 5- to 6-inch coleus were growing. The pots were drenched with tap water at the time of treatment and daily during the following week. Counts of mealybugs at the time of treatment indicated an average of 6.8 per leaf (20 leaves) in a range of 3 to 18 .

Data showed that 43 to 68 per cent of the mealybugs were dead on September 7 and 100 per cent on October 24. Although the coleus plants were growing intimately with untreated (continually infested) foliage plants, reinfestation of the treated ones did not occur for many months. 


\section{LITERATURE CITED}

Britton, W. E. 1901. First Report of the State Entomologist of Connecticut. Conn. Agr. Exp. Ann. Rep. 25-27, 1901-1903: 227-278.

Britton, W. E. 1933. Plant Pest Handbook. I. Insects. Conn. Agr. Exp. Sta. Bull. 344:66-190.

Cantelo, W. W. 1953. Life history and control of the euonymus scale in Mass. Agr. Expt. Sta., Univ. of Mass. Bull. 471:1-31.

Cockerell, T. D. A. 1897. The San Jose scale and its nearest allies. U.S.D.A. Div. Tech. Ser. No. 6:1-31.

Duda, E. J. 1957. A scale on hemlock. Scientific Tree Topics. 2(4):9.

Ehrlich, John. 1934. The beech bark disease. A nectaris disease of Fagus, following Cryptococcus fagi. Canadian Journal of Research, Vol. 10: 593-692.

Garman, Philip and J. F. Townsend. 1952. Control of apple insects. Conn. Agr. Exp. Sta. Bull. 552: 1-84.

Hawboldt, L. S. Nov. 1944. History of spread of the beech scale, Cryptococcus fagi (Baer) an insect introduced into the Maritime Provinces. Acadian Naturalist. Vol. 1, No. 4:137-146.

Hewitt, C. Gordon. 1914. Note on occurrence of the felted beech coccus Cryptococcus fagi (Baer.) Dougl. in Nova Scotia. Canadian Entol. 46:15-16.

Holbrook, J. E. R. Oct. 25, 1934. Report of scouting for the beech scale in the City of Hartford, Connecticut and neighboring towns.

McDaniel, E. I. 1931. Insects and allied pests of plants grown under glass. Mich. Agr. Expt. Sta. Sp. Bul. No. 214: 117 pp.

McDowell, D. N. 1960. Pests and diseases of trees and shrubs. Wisconsin State Dept. of Agr. Bull. 351:1-87.

Metcalf, C. L. and R. L. Flint. 1951. Destructive and Useful Insects. Third Edition. McGraw-Hill Book Co., Inc. 1071 pp.

Porter, H. L., O. W. Spilker and J. T. Walker. 1959. Control of Insects and Plant Diseases in the Nursery. Sixth Edition. 158 pp. Ohio Dept. of Agr., Div. Plant Industry.

Schread, John C. 1954. Scale insects and their control. Conn. Agr. Expt. Sta. Bull. 578: 1-23.

Schread, John C. 1961. Scales and mealybugs. Conn. Agr. Expt. Sta. Circ. 216: 1-11.

Shigo, Alex L. 1963. Beech bark scale. Northeastern Forest Expt. Sta., Forest Service, USDA Forest Pest Leaflet 75: 3 pp.

Steinweden, John B. 1946. Microentomology, Vol. II, Part 1: 1-28.

Wallner, W. E. 1964. Fiorinia hemlock scale, pest of ornamental hemlocks. Farm Research, N.Y. State Agr. Expt. Sta. and Cornell Agr. Exp. Sta. Vol. 30 (1): 1-3.

Weigel, C. A. and L. G. Baumhofer. 1948. Handbook of insect enemies of flowers and shrubs. USDA Miscellaneous Pub. 626: 1-115. 
THE CONNECIICUT

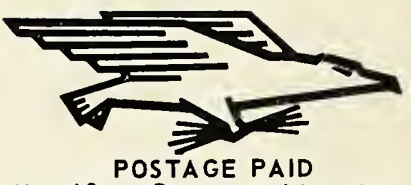

fams is thersfell

United States Department of Agriculture

PUBLICATION 


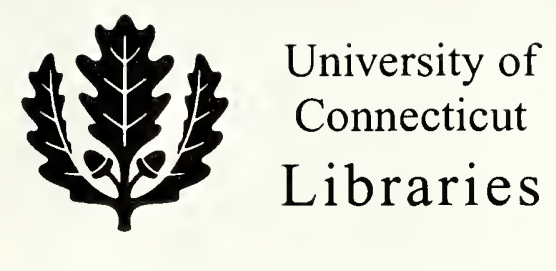


